\title{
Consensus
}

Volume 29

Issue 1 Hospitality - The Healing of the World

Article 13

$5-25-2003$

\section{Making sense of the Bible: Literary Type as an Approach to Understanding}

Carolyn Reimer

Follow this and additional works at: http://scholars.wlu.ca/consensus

\section{Recommended Citation}

Reimer, Carolyn (2003) "Making sense of the Bible: Literary Type as an Approach to Understanding," Consensus: Vol. 29 : Iss. 1 , Article 13.

Available at: http://scholars.wlu.ca/consensus/vol29/iss1/13

This Book Reviews is brought to you for free and open access by Scholars Commons @ Laurier. It has been accepted for inclusion in Consensus by an authorized editor of Scholars Commons @ Laurier. For more information, please contact scholarscommons@wlu.ca. 
Making Sense of the Bible:

Literary Type as an Approach to Understanding

Marshall D. Johnson

Grand Rapids: William B. Eerdmans, 2002

161 pages, $\$ 16.58$ Softcover

Making Sense of the Bible: Literary Type as an Approach to Understanding is a recent publication from biblical scholar and Christian theologian Marshall D. Johnson, whose books are often directed towards practical use by scholars, clergy and laity alike. For example, New Proclamation: Advent to Holy Week (2000) and New Proclamation: Year C, 2001: Easter through Pentecost (2000) address liturgical matters; The Purpose of the Biblical Genealogies: With Special Reference to the Setting of the Genealogies of Jesus (1989) reflects biblical scholarship; and The Young Bonhoeffer: 1918-1927 (Dietrich Bonhoeffer. Works, Vol 9) (2002) deals with theological concerns.

In Making Sense of the Bible Johnson offers a way of understanding the Bible by means of literary categories - from the literary type of Wisdom literature, including Proverbs, Job and Ecclesiastes; to apocalyptic literature, including Daniel and Revelation. The book consists of ten chapters (each approximately 10-15 pages in length) plus appendices. The chapters are straightforward. Johnson explains the literary type, and suggests which texts qualify by offering direct examples from the biblical text itself. By means of these examples, Johnson demonstrates the characteristics that determine why particular texts can be grouped together under a common genre. Each chapter concludes with suggestions for how readers might approach the various literary types.

The book's purpose is to make the Bible more accessible and applicable to readers today. Ideal readers of this book will be able to approach the Bible undaunted by the document as a whole, guided instead by their curiosity about particular literary genres. For example, a reader interested in texts concerning praise and worship can explore this area knowing which texts, and in some cases which sections within larger texts, fall under this literary category. In addition, the literary category itself can feed the interest of the reader, promoting greater curiosity, and understanding of issues such as 
authorship, context, and historicity. At the same time, Johnson seeks to promote greater reflexivity within the reader when it comes to his or her approach to the Bible.

The balanced consideration of both the readers' subjective concerns and the authors' intentions forms the basis of Johnson's study. Johnson's literary approach resonates with two other, wellknown approaches. First, it resembles reader-response method in that he explores what happens to the reader when he or she reads the text as if for the first time. Second, Johnson's approach draws on traditional historical-critical concerns. We see this most clearly in his search for the author's original intent, and his encouragement that readers suspend prior beliefs and expectations. Thus, Johnson proposes the literary type as a gateway to understanding the authors' intentions for their anticipated audiences, as well as a means to make the Bible more accessible to readers' concerns today.

While the writing is consistently clear and concise, further elaboration on his approach at the outset would help to clarify his chapters without rendering his text inaccessible. Nonetheless, Johnson's method is exemplified throughout the course of the book, which should provide readers with a solid understanding of what constitutes a particular literary type.

Making Sense of the Bible will likely appeal directly to its target audience: contemporary readers who are laypersons and have little or no formal biblical training, as well as clergy or professors of biblical studies who can use Marshall D. Johnson's book as a resource for teaching others how to study the Bible via particular literary genres. The book is accessible and practical, providing the necessary foundations and skills for readers to begin to identify and interpret literary forms in the Bible.

\section{Carolyn Reimer}

Department of Religious Studies

Wilfrid Laurier University

Waterloo, Ontario 